\title{
PERBANDINGAN ANGKA POSITIVITAS DAN WAKTU DETEKSI PERTUMBUHAN MYCOBACTERIUM TUBERCULOSIS ANTARA MEDIA BIAKAN CAIR KOLOROMETRIK DAN MEDIA PADAT OGAWA PADA SPESIMEN SPUTUM,CAIRAN PLEURA, DAN CAIRAN SEREBROSPINAL
}

\author{
Indahwaty, Ida Parwati, Arto Yuwono Soeroto, Noormartany \\ Bagian Patologi Klinik Fakultas Kedokteran Universitas Padjadjaran/ \\ Rumah Sakit Hasan Sadikin
}

\begin{abstract}
ABSTRAK
Biakan merupakan pemeriksaan baku emas untuk diagnosis tuberkulosis (TB). Pertumbuhan M. tuberculosis pada medium padat memerlukan waktu 3-4 minggu, sedangkan pada medium cair lebih cepat tumbuh. Penelitian ini bertujuan membandingkan angka positivitas dan waktu deteksi pertumbuhan $M$. tuberculosis antara medium cair kolorimetrik dan medium padat Ogawa. Penelitian dilakukan di Laboratorium Patologi Klinik RSHS periode JuniDesember 2007. Subjek penelitian adalah penderita tersangka TB paru, pleura, atau meningen. Analisis statistik menggunakan chi square dan independent t test. Spesimen penelitian terdiri dari 71 sputum, 24 cairan pleura, dan 20 cairan serebrospinal (CSS). Pada medium cair biakan positif $M$. tuberculosis dari sputum adalah $69 \%$, cairan pleura $41,7 \%$, CSS $60 \%$; pada medium padat dari sputum $52,1 \%$, cairan pleura $25 \%$, CSS $20 \%$. Angka positivitas medium cair berbeda bermakna untuk sputum dan CSS $(p<0,05)$. Rerata waktu deteksi pertumbuhan pada medium cair untuk sputum 15,2 $( \pm 8,7)$ hari, cairan pleura $8( \pm 12,7)$ hari, CSS $13,5( \pm 19,5)$ hari. Rerata waktu deteksi pertumbuhan pada medium padat untuk sputum $23( \pm 9)$ hari, cairan pleura $36( \pm 18,3)$ hari, dan CSS $32( \pm 11,4)$ hari. Waktu deteksi pertumbuhan $M$. tuberculosis pada medium cair berbeda bermakna untuk sputum dan cairan pleura $(p<0,05)$. Medium cair memberikan angka positivitas lebih tinggi dan waktu deteksi pertumbuhan $M$. tuberculosis lebih cepat dibandingkan medium padat, sehingga baik untuk diagnosis TB
\end{abstract}

Kata kunci: M. tuberculosis, sputum, cairan pleura, CSS, medium padat, medium cair, angka positivitas, waktu deteksi pertumbuhan

\section{COMPARISON OF THE POSITIVITY AND MEAN DETECTION TIME OF MYCOBACTERIUM TUBERCULOSIS GROWTH USING COLORIMETRIC LIQUID MEDIA AND OGAWA SOLID MEDIA WITH SPECIMENS FROM SPUTUM, PLEURAL FLUID AND CEREBROSPINAL FLUID}

\begin{abstract}
Cultivation is the gold standard in diagnosing tuberculosis (TB). M. tuberculosis needs 3-4 weeks to growth in solid media, but it is growing faster in liquid media. The aim of this study was to compare the positivity rate and detection time of M. tuberculosis growth using colorimetric liquid and Ogawa solid media. This study did in Laboratory of Clinical Pathology Hasan Sadikin Hospital during June-Desember 2007. The subject was pulmonary, pleuritis or meningitis TB patients. The statistic analyzed using chi square and independent $t$ test. The specimens were 71 sputums, 24 pleural fluids, 20 cerebrospinal fluids (CSF). The positivity rate of liquid media for sputums were $69 \%$, pleural fluids $41.7 \%$, CSF $60 \%$. The positivity rate of solid media for sputums were $52.1 \%$, pleural fluids $25 \%$, CSF $20 \%$. The positivity rate in liquid media was significant for sputum and CSF $(p \leq 0 . .05)$. The mean detection time in liquid media for sputums were $15.2( \pm 8.7)$ days, pleural fluids $8( \pm 12.7)$ days, CSF $13.5( \pm 19.5)$ days. The mean detection time in solid media for sputums $23( \pm 9)$ days, pleural fluids $36( \pm 18.3)$ days, CSF $32( \pm 11.4)$ days. The mean detection time in liquid media was significant for sputum and pleural fluid $(\mathrm{p} \leq 0.05)$. The positivity rate and detection time of M. tuberculosis growth in colorimetric liquid media are higher and faster than in Ogawa solid media, so it is better for diagnosing TB.
\end{abstract}

Key words: M. tuberculosis, sputum, pleural fluid, CSF, liquid media, solid media, positivity rate, mean detection time

\footnotetext{
Alamat Korespondensi: dr. Indahwaty, SpPK, M.Kes

Bagian Patologi Klinik Fakultas Kedokteran Universitas Padjadjaran/

Rumah Sakit Hasan Sadikin. Jl. Pasirkaliki no.190, Bandung 40161

Telp. (022) 2033307
} 


\section{PENDAHULUAN}

Tuberkulosis (TB) adalah penyakit infeksi bakteri kronik yang disebabkan oleh Mycobacterium tuberculosis complex. ${ }^{1}$ Beberapa kepustakaan membagi penyakit ini menjadi dua bagian besar yaitu TB paru dan TB ekstraparu. ${ }^{2-4}$

Penyakit TB masih merupakan masalah kesehatan di dunia. Pada tahun 1993 World Health Organization (WHO) mencanangkan kedaruratan global penyakit TB. Sebanyak 95\% penderita TB berada di negara berkembang dan yang terbanyak adalah di Asia. Indonesia menempati urutan ketiga kasus TB terbanyak setelah India dan Cina. ${ }^{5,6}$

Diagnosis pasti penyakit TB ditegakkan bila ditemukan bakteri $M$. tuberculosis di dalam spesimen, yang berasal dari organ yang terinfeksi, berdasarkan pemeriksaan bakteriologi. Sputum penderita TB paru aktif mengandung mikobakterium yang relatif banyak, karena sputum berasal dari kavitas di paru-paru. Beberapa spesimen yang berasal dari penderita TB ekstraparu, misalnya cairan pleura atau cairan serebrospinal (CSS), hanya mengandung sedikit mikobakterium (paucibacillary) ${ }^{3,4,7,8}$

Pemeriksaan bakteriologi terhadap $M$. tuberculosis terdiri atas pemeriksaan mikroskopis dan biakan. Pemeriksaan mikroskopis sputum penderita TB paru memiliki sensitivitas $50-70 \%,{ }^{4}$ cairan pleura $0-10 \%,{ }^{9,10}$ dan sensitivitas terhadap CSS sebesar $2-12 \%{ }^{7,8}$

Biakan $M$. tuberculosis merupakan pemeriksaan bakteriologi yang lebih sensitif daripada pemeriksaan mikroskopis ZN. Jenis media biakan secara umum terdiri dari dua macam, yaitu medium padat dan medium cair. ${ }^{11,12}$

Medium padat terdiri dari dua jenis, yaitu medium padat berbasis telur dan medium padat berbasis agar..$^{12-14}$ Medium padat berbasis telur merupakan pilihan pertama untuk biakan yang berasal dari spesimen sputum. Terdapat dua jenis medium padat berbasis telur, yaitu medium Lowenstein Jensen (LJ) dan medium Ogawa. Medium LJ digunakan secara luas di dunia, sedangkan medium Ogawa hanya digunakan di Jepang dan di Indonesia, khususnya di Laboratorium Mikrobiologi RSHS. Medium padat berbasis telur pembuatannya mudah, murah, dapat disimpan dalam waktu lama, dan juga dapat digunakan untuk identifikasi awal mikobakterium, tetapi medium ini memerlukan waktu yang lama untuk mendeteksi pertumbuhan $M$. tuberculosis dalam bentuk koloni (visible growth), yaitu selama 3-8 minggu. ${ }^{12-14}$

Medium cair terdiri dari beberapa jenis, antara lain Middlebrook 7H9 (medium cair konvensional), broth base culture system (Bactec 460TB, Septi-Check AFB, dan MGIT), dan yang terbaru adalah MB/BacT 240 yang menggunakan sistem kolorimetrik. Medium cair memiliki kemampuan mendeteksi pertumbuhan mikobakterium lebih cepat, terutama pada kasus TB ekstraparu, sehingga penggunaan medium ini akan sangat membantu para klinisi dalam menentukan diagnosis penyakit lebih dini. ${ }^{12,15-18}$

Tujuan penelitian ini adalah untuk membandingkan angka positivitas dan waktu deteksi pertumbuhan $M$. tuberculosis antara medium cair metode kolorimetrik dan medium padat metode konvensional Ogawa pada spesimen yang berasal dari penderita TB paru yaitu bahan pemeriksaan sputum dan spesimen yang berasal dari penderita TB ektraparu, yaitu bahan pemeriksaan cairan pleura dan CSS.

\section{METODE}

Penelitian dilakukan di Laboratorium Subbagian Mikrobiologi Klinik Bagian Patologi Klinik FKUP/ RSHS Bandung periode Juni-Desember 2007.

Kriteria inklusi subjek penelitian adalah penderita yang berusia lebih dari 14 tahun, didiagnosis kerja oleh klinisi sebagai penderita tersangka TB paru atau tersangka TB pleura dengan efusi atau tersangka TB meningen, dan penderita tidak sedang dalam terapi OAT atau dalam terapi OAT maksimal 2 bulan.

Sampel dikumpulkan secara sampling from consecutive admissions dari penderita TB paru/TB pleura/TB meningen yang telah memenuhi kriteria inklusi.

Bahan pemeriksaan adalah sputum, cairan pleura, dan CSS. Sputum diperoleh dengan cara berdahak dalam, ditampung di dalam wadah steril bermulut lebar (diameter \pm 35 $\mathrm{mm}$ ), kemudian diambil sebanyak 1 ose steril untuk dibuat sediaan apus pada beberapa kaca objek, sisanya dipindahkan kedalam tabung sentrifus steril yang bertutup ulir, lalu dilakukan digesti dekontaminasi menggunakan NALC$\mathrm{NaOH}$, sebanyak $\pm 0,2 \mathrm{~mL}$ ditanam dalam medium Ogawa (2 tabung) dan $\pm 0,5 \mathrm{~mL}$ ditanam dalam media cair lalu diinkubasi pada suhu 35$37^{\circ} \mathrm{C}$. Cairan pleura diambil melalui tindakan pungsi pleura yang dilakukan oleh klinisi di Bagian IImu Penyakit Dalam RSHS. Sebanyak $50 \mathrm{~mL}$ cairan pleura ditampung dalam tabung steril yang sudah berisi $500 \mu \mathrm{L}$ antikoagulan EDTA $10 \%$. Cairan pleura dalam tabung disentrifus $3.000 \mathrm{rpm}$ selama 15 menit, supernatan dibuang, disisakan sedimen seba-nyak $\pm 0,5$-1 $\mathrm{mL}$. Sedimen didigesti dekonta-minasi menggunakan NALC-NaOH. Sedimen diambil dengan pipet steril untuk dibuat apusan ZN, sisa sedimen ditanam dalam medium Ogawa dan pada media cair dengan perlakuan dan jumlah yang sama banyak seperti pada sputum. CSS diambil melalui pungsi lumbal oleh klinisi di Bagian Ilmu Penyakit Saraf RSHS. Volume yang diambil $\pm 10-15 \mathrm{~mL}$ atau disesuaikan dengan keadaan penderita. CSS ditampung kedalam 
kecepatan 3.000 rpm selama 15 menit. Super-natan dibuang disisakan sedimen sebanyak $\pm 0,5-1 \mathrm{~mL}$. Sedimen diisap dengan menggu-nakan pipet steril, 1 tetes diteteskan pada kaca objek, kemudian dibuat sediaan apus berdiame-ter $\pm 1 \mathrm{~cm}$ sebanyak 3 lapisan dengan menggu-nakan ose steril, lalu diwarnai dengan pewar-naan ZN. Sisa sedimen kemudian ditanam dalam medium Ogawa dan medium cair dengan perlakuan dan jumlah yang sama banyak seperti pada sputum dan cairan pleura.

Pertumbuhan M. tuberculosis disebut positif bila pada medium padat Ogawa terlihat bentuk koloni $M$. tuberculosis, yaitu koloni kasar seperti bunga kol dan berwarna kuning pucat, sedangkan pada medium cair kolorimetrik, pertumbuhan M. tuberculosis disebut positif bila ditemukan signal pada alat MB-BacT 240, dilanjutkan dengan konfirmasi menggunakan pemeriksaan mikroskopis ZN dan penanaman kembali pada medium padat Ogawa. Waktu deteksi pertumbuhan $M$. tuberculosis pada medium padat Ogawa dihitung mulai dari saat penanaman sampai terlihat bentuk koloni pada media, sedangkan waktu deteksi pertumbuhan M. tuberculosis pada medium cair kolorimetrik dihitung mulai dari penanaman sampai terlihat adanya signal pada alat.

Bentuk penelitian ini adalah observasional dengan rancangan penelitian cross sectional study. Metode analisis data yang digunakan untuk menganalisis perbandingan angka positivitas pertumbuhan mikobakterium pada media cair dan padat digunakan chi square, sedangkan untuk membandingkan waktu deteksi pertumbuhan mikobakterium digunakan independent test.

\section{HASIL}

Selama periode penelitian didapatkan 115 spesimen yang berasal dari 88 orang subjek penelitian yang terdiri atas 55 orang laki-laki dan 33 orang wanita. Usia subjek berkisar antara 17-79 tahun dengan median usia 38 tahun.

Spesimen penelitian terdiri atas 71 spesimen sputum, 24 cairan pleura, dan 20 CSS. Interpretasi pemeriksaan mikroskopis terhadap seluruh spesimen memberikan hasil negatif sebanyak $70,4 \%$ dan positif sebanyak $29,6 \%$. Positivitas pemeriksaan mikroskopis terutama diperoleh dari spesimen sputum $(42,5 \%)$, lalu cairan pleura $(4,2 \%)$, sedangkan pada spesimen CSS tidak dijumpai pemeriksaan mikroskopis yang positif (Tabel 1).

Angka positivitas pada medium cair secara keseluruhan dan pada masing-masing spesimen lebih tinggi dibandingkan dengan medium padat Ogawa. Hasil uji statistik dengan chi square pada derajat kepercayaan 95\% menunjukkan perbedaan bermakna angka positivitas medium cair MB/Bact 240 dengan angka positivitas medium padat Ogawa dari spesimen secara keseluruhan, spesimen sputum dan spesimen CSS, kedua spesimen ini memiliki nilai $p \leq 0,05$, sedangkan untuk spesimen cairan pleura tidak terdapat perbedaan bermakna ( $p>0,05)$ (Tabel 2).

Semua spesimen dengan hasil mikroskopis ZN positif memberikan hasil kultur yang positif pada medium cair MB/BacT maupun medium padat Ogawa. Pada penelitian ini terdapat sebanyak 81 spesimen dari 115 spesimen penelitian memiliki hasil pemeriksaan mikroskopis ZN awal negatif. Di antara 81 spesimen tersebut terdapat $45,7 \%$ hasil biakan pada MB/BacT positif dan 18,5\% hasil biakan pada Ogawa positif. Dari spesimen sputum, dari 38 ZN negatif, 42,1\% hasil biakan MB/BacT positif dan $13,2 \%$ hasil biakan Ogawa positif, spesimen cairan pleura, dari 23 ZN negatif terdapat 39,1\% hasil biakan MB/BacT positif dan 21,7\% hasil biakan Ogawa positif. Untuk spesimen CSS yang semua pemeriksaan mikroskopis ZN memberikan hasil negatif, didapatkan $60 \%$ hasil biakan pada MB/BacT positif dan 25\% hasil biakan pada Ogawa positif. Angka positivitas medium cair MB/BacT secara keseluruhan lebih tinggi dibandingkan dengan angka positivitas medium padat Ogawa pada spesimen dengan hasil pemeriksaan mikrokopis ZN negatif. Hasil uji statistik dengan chi square pada derajat kepercayaan 95\% menunjukkan terdapat perbedaan bermakna antara angka positivitas medium cair MB/Bact 240 dan angka positivitas medium padat Ogawa pada spesimen dengan hasil pemeriksaan mikrokopis ZN negatif dari seluruh spesimen, spesimen sputum dan spesimen CSS, ketiga spesimen ini memiliki nilai $p \leq 0,05$, sedangkan spesimen cairan pleura tidak terdapat perbedaan bermakna ( $p>0,05)$ (Tabel 3).

Rerata waktu deteksi pertumbuhan $M$. tuberculosis dari semua spesimen lebih cepat pada medium cair MB/BacT 240 dibandingkan dengan medium padat Ogawa.

Waktu deteksi pertumbuhan M. tuberculosis pada medium cair MB/BacT 240 berbeda secara bermakna untuk seluruh spesimen, sputum dan cairan pleura $(p \leq 0,05)$, sedangkan untuk CSS perbedaan ini tidak bermakna ( $p>0,05)$ (Tabel 4).

Penelitian ini mendapatkan beberapa kontaminasi pada medium padat maupun medium cair. Kontaminasi lebih banyak terjadi pada medium cair MB/BacT 240 (12,17\%) dibandingkan dengan medium padat Ogawa $(1,7 \%)$. Kontaminasi medium cair MB/BacT terbanyak terjadi pada spesimen sputum $(15,49 \%)$, kemudian cairan pleura $(12,5 \%)$, dan yang terendah adalah CSS (5\%) (Tabel 5).

\section{PEMBAHASAN}

Interpretasi hasil pemeriksaan mikroskopis pada 


\begin{tabular}{|c|c|c|c|c|c|c|c|c|}
\hline \multirow[t]{3}{*}{ ZN } & \multicolumn{8}{|c|}{ Spesimen } \\
\hline & \multicolumn{2}{|c|}{$\begin{array}{c}\text { Sputum } \\
(\mathrm{n}=71)\end{array}$} & \multicolumn{2}{|r|}{$\begin{array}{c}\mathrm{CPL} \\
(\mathrm{n}=24)\end{array}$} & \multicolumn{2}{|c|}{$\begin{array}{c}\text { CSS } \\
(n=20)\end{array}$} & \multicolumn{2}{|c|}{$\begin{array}{l}\text { Seluruh } \\
(n=115)\end{array}$} \\
\hline & $\mathbf{n}$ & $\%$ & $\mathbf{n}$ & $\%$ & $\mathrm{n}$ & $\%$ & $\mathbf{n}$ & $\%$ \\
\hline Negatif & 38 & 57,5 & 23 & 95,8 & 20 & 100 & 81 & 70,4 \\
\hline Scanty & 1 & 1,4 & & - & & - & 1 & 0,9 \\
\hline Pos 1 & 8 & 11,3 & 1 & 4,2 & & - & 9 & 7,8 \\
\hline Pos 2 & 9 & 12,7 & & - & & - & 9 & 7,8 \\
\hline Pos 3 & 15 & 21,1 & & - & & - & 15 & 13 \\
\hline
\end{tabular}

CPL $\leq$ cairan pleura; CSS $\leq$ cairan serebrospinal

Tabel 2 Perbandingan Angka Positivitas Pertumbuhan M. tuberculosis pada Medium Cair MB/BacT 240 dengan Medium Padat Ogawa dari Seluruh Spesimen, Sputum, dan Cairan

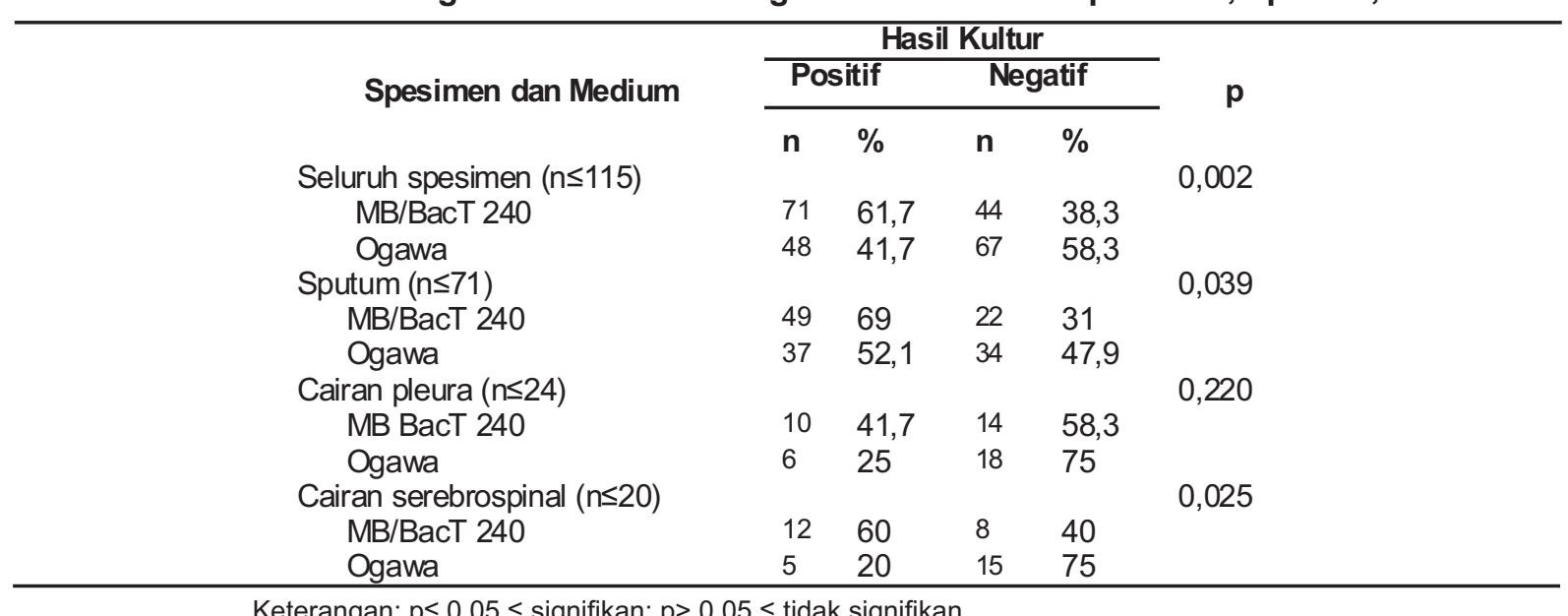

Tabel 3 Perbandingan Angka Positivitas Medium Cair MB/BacT 240 dan Medium Padat Ogawa dari Spesimen dengan Hasil Mikroskopis ZN Negatif

\begin{tabular}{|c|c|c|c|c|c|c|c|c|}
\hline \multirow[b]{2}{*}{ Media Biakan } & \multicolumn{8}{|c|}{ Spesimen } \\
\hline & \multicolumn{2}{|c|}{$\begin{array}{l}\text { Seluruh } \\
(\mathrm{n}=81)\end{array}$} & \multicolumn{2}{|c|}{$\begin{array}{c}\text { Sputum } \\
(\mathrm{n}=38)\end{array}$} & \multicolumn{2}{|c|}{$\begin{array}{c}\text { CPL } \\
(n=23)\end{array}$} & \multicolumn{2}{|c|}{$\begin{array}{c}\text { CSS } \\
(n=20)\end{array}$} \\
\hline MB/ BacT 240 & $\begin{array}{c}\mathbf{n} \\
37\end{array}$ & $\begin{array}{c}\% \\
45,7\end{array}$ & $\begin{array}{c}\mathbf{n} \\
16\end{array}$ & $\begin{array}{c}\% \\
42,1\end{array}$ & $\begin{array}{l}\mathrm{n} \\
9\end{array}$ & $\begin{array}{c}\% \\
39,1\end{array}$ & $\begin{array}{c}\mathbf{n} \\
12\end{array}$ & $\begin{array}{l}\% \\
60\end{array}$ \\
\hline Ogawa & 15 & 18,5 & 5 & 13,2 & 5 & 21,7 & 5 & 25 \\
\hline $\mathrm{p}$ & & & & & & & & \\
\hline
\end{tabular}

$\mathrm{CPL} \leq$ cairan pleura; CSS $\leq$ cairan serebrospinal

Tabel 4 Perbandingan Waktu Deteksi Pertumbuhan M. tuberculosis Antara Medium Cair B/BacT 240 dan Medium Padat Ogawa pada Spesimen Sputum, Cairan Pleura, dan CSS

\begin{tabular}{lcccc}
\hline & $\begin{array}{c}\text { Seluruh spesimen } \\
\text { (hari) }\end{array}$ & $\begin{array}{c}\text { Sputum } \\
\text { (hari) }\end{array}$ & $\begin{array}{c}\text { CPL } \\
\text { (hari) }\end{array}$ & $\begin{array}{c}\text { CSS } \\
\text { (hari) }\end{array}$ \\
\hline MB/BacT & & & & \\
Rerata & 15,86 & 15,21 & 13,4 & 20,25 \\
SB & 12 & 8,7 & 12,73 & 19,54 \\
Rentang & $2-69$ & $2-38$ & $2-35$ & $2-69$ \\
Ogawa & & & & \\
Rerata & 26,37 & 24,39 & 34,67 & 31,40 \\
SB & 11,05 & 9,01 & 18,33 & 11,40 \\
Rentang & $10-65$ & $14-56$ & $10-65$ & $19-45$ \\
p & $<0,001$ & $<0,001$ & 0,016 & 0,160 \\
\hline
\end{tabular}

Keterangan: $\mathrm{SB} \leq$ simpangan baku; $\mathrm{CPL} \leq$ cairan pleura; $\mathrm{CSS} \leq$ cairan serebrospinal 
Tabel 5 Kontaminasi pada Medium Cair MB/BacT 240 dan Medium Padat Ogawa

\begin{tabular}{|c|c|c|c|c|c|c|c|c|}
\hline \multirow[t]{2}{*}{ Kontaminasi } & \multicolumn{2}{|c|}{$\begin{array}{l}\text { Seluruh spesimen } \\
\qquad(n=115)\end{array}$} & \multicolumn{2}{|r|}{$\begin{array}{c}\text { Sputum } \\
(n=71)\end{array}$} & \multicolumn{2}{|c|}{$\begin{array}{c}\text { CPL } \\
(n=24)\end{array}$} & \multicolumn{2}{|c|}{$\begin{array}{c}\text { CSS } \\
(n=20)\end{array}$} \\
\hline & $\mathbf{n}$ & $\%$ & $\mathbf{n}$ & $\%$ & $\mathbf{n}$ & $\mathrm{n} \%$ & $n$ & $\%$ \\
\hline MB/Bact 240 & 14 & 12,17 & 11 & 15,49 & 3 & 12,5 & 1 & 5 \\
\hline Ogawa & 2 & 1,7 & 1 & 1,4 & 1 & 4,1 & & - \\
\hline
\end{tabular}

penelitian ini, angka positivitas tertinggi didapatkan dari spesimen sputum $(42,5 \%)$, kemudian cairan pleura $(4,2 \%)$, dan tidak ada hasil positif pada spesimen CSS. Beberapa kepustakaan menyebutkan bahwa spesimen sputum dari penderita TB paru aktif mengandung mikobakterium yang relatif banyak karena berasal dari kavitas yang pecah, sedangkan untuk spesimen cairan tubuh dari penderita TB ekstraparu bersifat paucibacillary. ${ }^{3,4,7,8}$ Pemeriksaan mikroskopis dengan pewarnaan ZN akan memberikan hasil positif bila jumlah bakteri dalam spesimen $>5.000 \mathrm{BTA} / \mathrm{mL}^{14}$ Aggarwal dkk. $^{10}$ dalam penelitiannya menemukan $10 \%$ pemeriksaan mikroskopis ZN untuk spesimen cairan pleura yang positif dari penderita TB pleura, sedangkan $\mathrm{Haa}^{9}$ mendapatkan $0-1 \%$. Hasil pemeriksaan mikroskopis ZN spesimen CSS pada penelitian ini lebih rendah daripada penelitian Kumar dkk. ${ }^{8}$ dan Hooker dkk. ${ }^{7}$ bahkan $100 \%$ negatif. Tetapi hasil biakan spesimen CSS positif pada 12 dari 20 spesimen. Secara teori, jumlah bakteri yang diperlukan untuk memberikan hasil biakan positif adalah \pm 10 $\mathrm{BTA} / \mathrm{mL},{ }^{19}$ sehingga hasil pemeriksaan mikroskopis negatif dari beberapa spesimen CSS yang ternyata memiliki hasil biakan positif disebabkan jumlah bakteri di dalam spesimenspesimen tersebut hanya mengandung bakteri kurang dari $5.000 \mathrm{BTA} / \mathrm{mL}$.

Pada penelitian ini, angka positivitas pada medium cair secara keseluruhan dan pada masing-masing spesimen lebih tinggi dibandingkan dengan medium padat Ogawa. Secara teori, M. tuberculosis memiliki dinding sel yang sangat kaya akan lemak, bersifat hidrofobik, dan selalu tumbuh dalam bentuk clump (gumpalan), sehingga nutrisi yang tersedia di media padat sulit untuk diambil oleh masing-masing bakteri. ${ }^{19,20}$ Sedangkan di dalam medium cair, M. tuberculosis dapat tersuspensi dalam cairan sehingga dapat tersebar ke segala arah dan seluruh permukaan bakteri dapat berkontak dengan nutrien di dalam media untuk memperoleh sumber nutrisinya. ${ }^{20}$ Oleh karena itu, angka positivitas pertumbuhan $M$. tuberculosis pada medium cair lebih tinggi dibandingkan dengan angka positivitas pada medium padat.

Beberapa penelitian terdahulu membandingkan angka positivitas antara berbagai metode medium cair dan medium padat Lowenstein-Jensen (LJ) pada berbagai spesimen dan tidak dilaporkan per spesimen, belum ada penelitian yang membandingkan ang- ka positivitas antara medium cair MB/BacT 240 dan medium padat Ogawa.

Penelitian ini menggunakan medium padat Ogawa modifikasi, yang merupakan medium padat yang digunakan oleh Laboratorium Mikrobiologi Klinik Bagian Patologi Klinik RSHS. Medium ini digunakan oleh Laboratorium Mikrobiologi Klinik karena pembuatannya mudah, dari bahan-bahan yang mudah didapat, harganya murah dan memiliki kadar bufer asam yang lebih tinggi dari medium padat LJ (kadar $\mathrm{KH}_{2} \mathrm{PO}_{4}$ Ogawa 3\%, kadar $\mathrm{KH}_{2} \mathrm{PO}_{4} \mathrm{LJ} 0,4 \%$ ). ${ }^{12-14}$

Angka positivitas pertumbuhan $M$. tuberculosis pada medium cair MB/BacT 240 pada penelitian ini lebih tinggi dari penelitian Oberoi dan Kaur. ${ }^{18}$ Dalam penelitian mereka, 500 spesimen yang ditanam dalam medium cair MB/Bact 240 dan medium padat LJ, angka positivitas pada MB/BacT 240 adalah $16,4 \%$ dan angka positivitas pada medium LJ adalah 2,2\%.

Beberapa penelitian lain mendapat angka positivitas yang lebih tinggi tetapi berasal dari spesimen yang hasil biakannya positif. Penelitian-penelitian tersebut antara lain adalah penelitian Tortoli dkk., ${ }^{15}$ Rohner dkk., ${ }^{16}$ serta Mirovic dan Lepzanovic. ${ }^{17}$ Penelitian-penelitian ini menggunakan lebih dari seribu spesimen yang terdiri dari berbagai jenis spesimen, Hasil kultur positif dari seluruh spesimen adalah 6,8$10,8 \%$. Dari hasil kultur yang positif, angka positivitas pertumbuhan $M$. tuberculosis pada medium cair (MB/BacT 240, Bactec 460, dan MGIT) adalah antara $80-93,2 \%$, sedangkan angka positivitas dan pada medium LJ adalah antara $67,3-79,5 \%$. Pada penelitian ini didapatkan hasil kultur positif lebih tinggi yaitu $61,7 \%$, hasil kultur positif seluruhnya berasal dari medium MB/BacT 240 (100\%) dan bila dihitung dari hasil kultur positif, maka angka positivitas Ogawa adalah $67,60 \%$. ${ }^{15-17}$

Angka positivitas pertumbuhan $M$. tuberculosis dari spesimen pleura pada medium cair lebih tinggi dibandingkan dengan medium padat Ogawa, tetapi perbedaan ini secara statistik tidak bermakna. Beberapa faktor berpengaruh terhadap pertumbuhan $M$. tuberculosis, antara lain karakteristik cairan pleura serta proses digesti dan dekontaminasi. Berbeda dengan sputum yang memiliki karakteristik tidak steril (memiliki banyak flora normal), sehingga proses digesti dekontaminasi untuk spesimen sputum menggunakan larutan NALC-NaOH $4 \%$ sesuai anjuran $\mathrm{WHO},{ }^{11-14,19}$ karakteristik cairan pleura adalah steril (tidak ada 
flora normal) dan cairan pleura pada penderita TB pleura hanya sedikit mengandung M. tuberculosis. ${ }^{3,10}$ Pengolahan spesimen cairan pleura pada penelitian ini menggunakan konsentrasi $\mathrm{NaOH} 4 \%$ dalam larutan NALC$\mathrm{NaOH}$ untuk proses digesti dan dekontaminasi; berdasarkan kepustakaan, $\mathrm{NaOH} 4 \%$ selain dapat membunuh bakteri kontaminan, juga dapat membunuh M. tuberculosis sebanyak 50$80 \%$ dari jumlah semula. ${ }^{12,14}$ Cairan pleura karakteristiknya steril dan hanya mengandung sedikit mikobakterium, ${ }^{3,10}$ bila menggunakan $\mathrm{NaOH} 4 \%$ dapat membunuh $M$. tuberculosis yang ada dalam cairan pleura tersebut. Oberoi dan Kaur ${ }^{18}$ menggunakan $\mathrm{NaOH}$ dengan konsentrasi $2 \%$ dan mendapatkan hasil yang signifikan pada angka positivitas pertumbuhan $M$. tuberculosis. Perlu dilakukan penelitian lebih lanjut mengenai konsentrasi $\mathrm{NaOH}$ yang paling baik untuk proses digesti dekontaminasi spesimen cairan pleura.

Pada penelitian ini terdapat 81 dari 115 spesimen memiliki hasil pemeriksaan mikroskopis ZN awal negatif. Hasil biakan pada MB/ BacT 240 memberikan hasil positif lebih tinggi daripada hasil biakan pada medium padat Ogawa untuk spesimen sputum, cairan pleura, dan CSS yang memberikan hasil pemeriksaan mikroskopis ZN negatif. Hal ini menunjukkan bahwa pada medium cair MB/BacT 240, $M$. tuberculosis lebih mudah tumbuh dibandingkan dengan medium padat Ogawa, sehingga medium cair MB/BacT lebih baik digunakan terutama untuk spesimen yang hanya sedikit mengandung mikobakterium.

Waktu deteksi pertumbuhan $M$. tuberculosis pada medium cair MB/BacT 240 berbeda secara bermakna untuk seluruh spesimen, sputum, dan cairan pleura $(p \leq 0,05)$, sedangkan untuk CSS perbedaan ini tidak bermakna $(p>0,05)$. Hal ini disebabkan ada satu spesimen CSS yang memiliki waktu deteksi pertumbuhan yang lama yaitu 69 hari, tetapi hasil kultur Ogawa pada spesimen ini negatif.

Rerata waktu deteksi pertumbuhan $M$. tuberculosis dari spesimen cairan pleura pada medium cair MB/BacT adalah yang paling cepat di antara semua spesimen, sedangkan rerata waktu deteksi pertumbuhan $M$. tuberculosis pada medium padat Ogawa paling lambat di antara semua spesimen. Pada penelitian ini ada satu spesimen cairan pleura yang berasal dari penderita TB diseminata, memiliki jumlah bakteri $>5.000 \mathrm{BTA} / \mathrm{mL}$, sehingga pemeriksaan mikroskopis ZN spesimen ini positif, waktu tumbuh pada medium cair MB/BacT hanya dua hari dan hasil konfirmasi ZN langsung positif, waktu tumbuh pada medium padat Ogawa hanya 10 hari. Ada juga satu spesimen cairan pleura yang mengandung BTA dan jamur, sehingga mikobakterium harus berkompetisi dengan jamur untuk dapat tumbuh di medium. Spesimen ini memberikan hasil pemeriksaan mikroskopis ZN negatif, waktu tumbuh pada medium cair MB/BacT 35 hari, dan waktu tumbuh pada medium padat Ogawa 65 hari.

Rerata waktu deteksi pertumbuhan pada penelitian ini tidak jauh berbeda dengan hasil penelitian-penelitian sebelumnya. Oberoi dan $\mathrm{Kaur}^{18}$ mendapatkan rerata waktu deteksi pertumbuhan pada medium cair MB/BacT adalah 16 hari, sedangkan rerata waktu deteksi pertumbuhan pada medium padat LJ adalah 26 hari. Mirovic dan Lepzanovic ${ }^{17}$ mendapatkan rerata waktu deteksi pertumbuhan pada medium cair MB/BacT 240 adalah 13,8 hari dan rerata waktu deteksi pertumbuhan pada medium padat LJ adalah 22,1 hari. Demikian juga dengan Rohner dkk. ${ }^{16}$ mendapatkan rerata waktu deteksi pertumbuhan pada MB/BacT adalah 17,5 hari, rerata waktu deteksi pertumbuhan pada Bactec 460 adalah 14,3 hari, dan rerata waktu deteksi pertumbuhan pada medium padat LJ adalah 24,2 hari. Tortoli $\mathrm{dkk} .{ }^{15}$ mendapatkan rerata waktu deteksi pertumbuhan pada medium cair MGIT adalah 13,3 hari, rerata waktu deteksi pertumbuhan pada medium cair Bactec 460 adalah 14,8 hari, dan rerata waktu deteksi pertumbuhan pada medium padat LJ adalah 25,6 hari.

Penelitian ini mendapatkan beberapa kontaminasi pada medium padat maupun medium cair. Kontaminasi lebih banyak terjadi pada medium cair MB/BacT 240 dibandingkan dengan medium padat Ogawa. Kontaminasi medium cair $\mathrm{MB} / \mathrm{BacT}$ terbanyak terjadi dari spesimen sputum, kemudian cairan pleura, dan yang terendah adalah CSS.

Kontaminasi pada botol medium cair $\mathrm{MB} / \mathrm{BacT}$ dapat diketahui pada saat awal konfirmasi dengan pemeriksaan mikroskopis $\mathrm{ZN}$, atau dapat juga diketahui pada saat akhir konfirmasi. Kontaminasi pada awal konfirmasi untuk spesimen sputum adalah yang terbesar di antara semua spesimen, yaitu enam dari 11 kontaminasi yang terjadi pada spesimen ini $(54,54 \%)$, sedangkan pada spesimen pleura kontaminasi lebih banyak terjadi di akhir konfirmasi yaitu dua dari tiga kontaminasi $(66,66 \%)$. Demikian juga dengan spesimen CSS, kontaminasi hanya terjadi pada akhir kontaminasi (100\%). Hal ini sesuai dengan karakteristik sputum yang mengandung banyak flora normal, sehingga spesimen masih mengandung mikroorganisme lain meskipun sudah dilakukan proses digesti-dekontaminasi, sedangkan karakteristik cairan pleura relatif steril, hanya satu penderita yang spesimen pleuranya dari awal sudah mengandung mikroorganisme lain selain mikobakterium, selebihnya kontaminasi terjadi pada akhir konfirmasi.

Pada penelitian yang dilakukan oleh Oberoi dan Kaur, ${ }^{18}$ jumlah kontaminasi yang terjadi pada medium MB/BacT 240 adalah 14,4\%, tidak jauh berbeda dengan penelitian ini. Pada penelitian 
Oberoi dan Kaur $^{18}$ didapatkan jumlah kontaminasi medium padat LJ lebih tinggi dibandingkan kontaminasi pada medium MB/BacT yaitu $24,4 \%$, angka ini lebih tinggi dibandingkan dengan jumlah kontaminasi Ogawa pada penelitian ini.

Beberapa hal yang dapat berpengaruh terhadap terjadinya kontaminasi, terutama pada medium cair MB/BacT adalah: spesimen memang sudah mengandung mikroorganisme dalam jumlah banyak, sehingga proses dekontaminasi tidak dapat membunuh habis semua mikroorganisme kontaminan ini. Proses pengambilan contoh cairan dari MB untuk konfirmasi, perlu mengeluarkan botol dari inkubator, dilakukan vorteks pada safety cabinet. Kontaminasi dapat terjadi selama proses ini karena tutup botol harus ditusuk untuk mengambil contoh cairan. Mikroorganisme kontaminan dari lingkungan sekitar dapat masuk melalui lubang bekas tusukan ini.

Diperlukan tindakan yang lebih berhatihati dalam proses konfirmasi pertumbuhan $M$. tuberculosis pada botol-botol medium cair $\mathrm{MB} / \mathrm{Bac} T$ untuk meminimalisasi kejadian kontaminasi.

Berdasarkan hasil penelitian ini, dapat disimpulkan bahwa medium cair metode kolorimetrik memiliki angka positivitas dan waktu deteksi pertumbuhan lebih cepat untuk biakan $M$. tuberculosis dibandingkan dengan medium padat metode konvensional Ogawa, sehingga medium cair metode kolorimetrik lebih baik digunakan untuk diagnosis TB paru maupun ekstraparu.

\section{DAFTAR PUSTAKA}

1. Daniel TM. Tuberculosis. Dalam: Braunwald E, Isserbacher KJ, Petersdorf RG, Wilson JD, Martin JB, Fauci AS (penyunting). Harrison's principles of internal medicine. Edisi ke-11. Philadelphia: Mc Graw Hill Co; 1987. hlm. 62532.

2. Dutt AK. Epidemiology and host factors. Dalam: Schlossberg D (penyunting). Tuberculosis \& non tuberculous Mycobacterial infections. Edisi ke-5. NY: Mc. Graw Hill \& Co; 2006. hlm. 1-17.

3. Sharma SK, Mohan A. Extrapulmonary tuberculosis. Indian J Med Res. 2004;120:31653.

4. Iseman MD. Aclinician guide to TB. Philadelphia: Lipincot William\& Wilkins; 2000.

5. WHO. Global TB Control 2006 (diunduh 19 Juni 2006). Tersedia dari: http://www.who.int/tb/ publication/global_report/en

6. Departemen Kesehatan Republik Indonesia. Pedoman Nasional Penanggulangan Tb. Edisi ke-8. Jakata: Dirjen P2M\&PLP. Depkes RI; 2002.
Ligeyo SO, Bhatt KM, Odhiambo JA. Diagnostic utility of cerebrospinal fluid studies in patients with cinically suspected TBM. Int J Tuber Lung Dis. 2003;7(8):787-96.

8. Kumar R, Singh SN, Kohli N. A dignostic rule for tuberculous meningitis. Arc Dis Child. $1999 ; 81: 221-4$.

9. HAa DW. Mycobacterial disease. Dalam: Mandell $F$ (penyunting). Principles and practice of infection disease. Edisi ke-5. Philadelphia: Churchill Livingstone of Hartcourt Health Service Co; 2000. hlm. 378-86.

10. Aggarwal AN, Gupta D, Jindal SK. Diagnosis of tubercular pleural effusion. Indian J Chest Diss Allied Sci. 1999;41:89-100.

11. Vossier JM. Mycobacterium tuberculosis complex and other non tuberculous Mycobacterium. Dalam: Mahon CR, Manusselis $G$ (penyunting). Textbook of diagnosis microbiology. Edisi ke-2. Philadelphia: WB Saunders Company; 2000. hlm. 669-707.

12. Forbes BA, Sahn DF, Weissfeld AS. Bailey \& Scott's diagnostic microbiology. Edisi ke-10. St. Louis: Mosby inc; 1998.

13. Pfyffer GE, Graveinitz A, The microbiology of Mycobacterium tuberculosis. Tuberculosis. Eur Resp Soc J. 1997;2:14-29.

14. Weyer K Laboratory services in tuberculosis control. Part III: culture. Geneva: WHO; 1998.

15. Tortoli E, Chichero P, Piersimoni C, Simonetti MT, Gesu G, Nista D. Use of Bactec 460 and MGIT 960 for recovery of Mycobacteria from clinical specimen: Multicenter study. JCM. 1999;37(11):3578-82.

16. Rohner $P$, Ninet $B$, Metral $C$, Emler $S$, Auckenthaler R. Evaluation of the MB/BacT system and comparison to the BACTEC 460 system and solid media for isolation of Mycobacteria from clinical specimens. JCM. 1997;35(12):3127-31.

17. Mirovic P, Lepzanovic Z. Evaluation of MB/BacT system for recovery of from clinical specimens in comparison to Lowenstein-Jensen Medium. Clin Microb Infect. 2002;8:709-14.

18. Oberoi A, Kaur H. Comparison of rapid colorimetric method with conventional method in the isolation of Mycobacterium tuberculosis. Indian J Med Microb. 2004;22(1):44-6.

19. Marshall BG, Shaw RJ. Diagnostic tehcniques: old and new. Eur Resp Mon. 1997;4:30-50.

20. Wayne LG. Cultivation of Mycobacterium for research purposes. Dalam: Bloom BR, penyunting. Tuberculosis: pathogenesis, protection and control. Washington DC: ASM Press; 1994. h. 73-82. 